\title{
DESCRIPTION OF THELANDROS AEGYPTI (NEMATODA: PHARYNGODONIDAE) FROM THE EGYPTIAN SPINY-TAILED LIZARD, UROMASTYX AEGYPTIA (SQUAMATA: AGAMIDAE) IN EGYPT By
}

\author{
FATHY M. ABDEL-GHAFFAR ${ }^{1}$, HUDA EL-FAYOUMI', \\ HEBA ABDEL-HALEEM ${ }^{2}$, SARA A. MOHAMED ${ }^{2 \star}$ AND KAREEM MORSY ${ }^{1}$ \\ Department of Zoology, Faculty of Science, Cairo University ${ }^{1,}$ Giza and Department \\ of Zoology, Faculty of Science, Beni-Suef University ${ }^{2}$, Beni-Suef, Egypt \\ ( ${ }^{*}$ Correspondence: sara_aly_1989@yahoo.com)
}

\begin{abstract}
Thelandros aegypti (Nematoda: Pharyngodonidae) isolated from the large intestine of the Egyptian spiny-tailed lizard, Uromastyx aegyptia, in North Sinai deserts, Egypt were described by means of light microscopy as a first description from this host in Egypt. 18 out of 25 (72\%) of the examined specimens were naturally infected. The recovered nematodes characterized by the followings; the mouth bounded by three bilobed lips, the presence of three pairs of caudal papillae in male, the absence of gubernaculums, the post-equatorial vulva and the tail of female was suddenly constricted behind anus to form a terminal spike. Male was cylendrical with distinct posterior truncation, 3.0 (2.71-3.7) mm long; 0.24 (0.20-0.33) mm wide. Three pairs of anal Papillae were recorded; the first and the second were pre and perianal and the last pair immediately behind the rounded posterior region of the worm. The tail was narrow, sharply pointed and measured 0.052-0.072 $\mathrm{mm}$ in length with selender spicule measured $0.045-0.077 \mathrm{~mm}$ long. Female was 4.34 (3.32-4.73) $\mathrm{mm}$ long, 0.29 (0.24-0.39) mm wide, vulva was post-equatorial, ovary was amphidelphic, the anterior part extended to the level of excretory pore and the posterior ovary extended posteriorly to the anal opening. Uteri were divergent. Egg was oval, slightly flattened and measured 65.4-79.2 $\mu \mathrm{m}$ long and 44.3-74 $\mu \mathrm{m}$ wide.

The described parasite was compared with different species of the same genus from different hosts. It was found that morphometrically, the present species was more or less different from the comparable species and the only morphologically similar species was Thelandros aegypti.
\end{abstract}

Key words: Thelandros aegypti, Nematoda, Uromastyx aegyptia, Agamidae, North Sinai, Egypt

\section{Introduction}

Genus Thelandros was erected by Wedl (1861) for T. alatus, a nematode from the intestine of an Egyptian mastigure, Uromastyx aegyptia. Chatterji (1933) described Parapharyngodon maplestoni from the intestine of an oriental garden lizard, Calotes versicolor, collected in Burma. The differentiation between Parapharyngodon (Chatterji, 1933) and Thelandros (Wedl, 1861) was controversial by reason of the morphological similarities. Some authors considered them as synonym (Baylis, 1936; Karve, 1938; García-Calvente, 1948; Skryabin et al, 1951). However, Freitas (1957) considered them as different genera as did (Sharpilo, 1976; Adamson, 1981; Baker, 1987; Castaño-Fernandez et al, 1987; Hering-Hagenbeck et al, 2002). Adamson (1981) redefined Paraph- aryngodon and Thelandros and distinguished both based on the host dietary habits, the male and female caudal morphology and egg structure. Males of Thelandros have a genital cone with pendulant papillae located outside this cone with an accessory piece present in some species and terminal posteriorly directed tail. But, Parapharyngodon spp. males lack the genital cone and the accessory piece. Also, they have mammilliform papillae surrounding the more-or-less terminal anus, lateral alae and subterminal dorsally directed tail (Ramallo et al, 2002; Bursey and Goldberg, 2005; Dung et al, 2009). Thelandros females have various tail morphologies; eggs have a terminal operculum and are larvated when released. Parapharyngodon spp. females with a conical tail ending in a short stout spike, eggs with sub 
terminal operculum and are in the early stages of cleavage when released (Ra-mallo et al, 2002; Bursey and Goldberg, 2005). Genus Thelandros (Wedl, 1861) is characterized by their haplodiploidy, direct lifecycle and essentially parasites of omnivorous and herbivorous reptiles (Adamson, 1989; 1990; Roca, 1999; Dung et al, 2009). More than 30 species are assigned to the genus Thelandross (Bursey and Goldberg, 2005); however the taxonomic status of some species is still under discussion.

The Egyptian spiny-tailed lizard Uromastyx aegyptia (Forskål, 1775) was reported in Egypt, Libya, Palestine, Israel and other countries throughout the Middle East (Baha El Din and Sherif, 2006; Nemtzo, 2008). It is by far the largest species of the genus Uromastyx with a maximum body length of more than $700 \mathrm{~mm}$ and a weight of up to 2,500g (Wilms et al, 2010). This lizard is active during the day time, they basking at the burrow entrance to warm up before heading out to forage for leaves, buds, fruits, seeds and flowers (Nemtzo, 2008). They are even known to be predacious, especially as juveniles, on arthropods (Cunningham, 2000).

The present study described the nematode isolated from the large intestine of the Egyptian spiny-tailed lizard, Uromastyx aegyptia on the basis of light microscopy.

\section{Materials and Methods}

During the period from May to October 2017, twenty-five specimens of the Egyptian spiny-tailed lizard, Uromastyx aegyptia were collected by noosing or hand from the plains of North Sinai, Egypt. Hosts were killed by using $20 \%$ benzocaine gel (Anbesol, Pfizer, Inc., New York, New York). Upon necropsy, the body cavity was opened by a longitudinal incision from vent to throat and the gastrointestinal tract was removed and examined searching for helminths with the use of stereomicroscope. All animal procedures were carried out according to the regulatory laws regarding experimental Animal Ethics Committee, Faculty of Science,
Beni-Suef University, Egypt (Ethical Approval Number: 2015/10). Nematodes found were heat fixed in $10 \%$ neutral buffered formalin for $15 \mathrm{~min}$ and then preserved in $70 \%$ ethanol in $5 \%$ glycerol solution to avoid sudden drying. Finally, samples were transferred to lactophenol for clearance. The prepared samples were examined using differential interference contrast (DIC) light microscopy with digital image analysis system (analysis auto 5.0). Measurements were in $\mathrm{mm}$ unless otherwise stated.

\section{Results}

A total of 18/25 (72.0\%) specimens of the Egyptian spiny-tailed lizard $U$. aegyptia were infected with nematode parasites.

Thelandros aegypti Amer (2004) based on 12 specimens (Figs. 1-7): Robust cylindrical nematodes with prominent cuticle annulations from beginning of oesophagus and continuing to anal opening. Body tapered at both ends. The oral opening was surrounded by three bilobed lips. Male posterior extremity truncated; caudal alae absent; spicule short, sharp, pointed and gubernaculum absent. The tail of female is suddenly constricted behind anus and vulva positioned little behind the middle of body.

Male: Cylendrical body with distinct posterior truncation, measured 3.0 (2.71-3.7 $\mathrm{mm})$ in length; $0.24(0.20-0.33 \mathrm{~mm})$ in width. Length of oesophagus (including bulb) was $0.58(0.41-0.72 \mathrm{~mm})$. Nerve ring and excretory pore were $55-100 \mu \mathrm{m}(80 \pm 7)$ and 44 $84(56 \pm 5)$ from anterior end respectively. Testes situated at the mid-body. Three pairs of anal papillae; the first and the second were pre and perianal and the last pair immediately behind the worm rounded posterior region. The tail was narrow, sharply pointed and measured $0.052-0.072 \mathrm{~mm}$ in length. The slender spicule measured 0.045$0.077 \mathrm{~mm}$ in length.

Female: Body length 4.34 (3.32-4.73 mm); width $0.29(0.24-0.39 \mathrm{~mm})$. Total esophagus length 0.87 (0.76-0.98 mm). Bulb length was $89-170 \mu \mathrm{m}$ (153 \pm 18$)$; bulb width $85-120$ 
$\mu \mathrm{m}(96 \pm 10)$. Nerve ring and excretory pore were $66-116 \mu \mathrm{m}(84 \pm 7)$ and $40-83(52 \pm 6)$ respectively from anterior end. Vulva was post-equatorial. Ovary was amphidelphic, the anterior part extended to the level of excretory pore and the posterior ovary extended posteriorly to anal opening. Uteri were divergent. Egg was oval, slightly flattened and measured $65.4-79.2 \mu \mathrm{m} \times 44.3-74 \mu \mathrm{m}$.

Taxonomic summary:

Type species: Thelandros aegypti Amer (2004)

Type-host: Uromastyx aegyptia (Agamidae)

Site of infection: Large intestine

Type locality: North Sinai Governorate, Egypt

Prevalence: Eighteen out of 25 (72.0\%) specimens were infected

Deposition: Permanent slides of paratype female and holotype male were deposited in Department of Zoology Museum, Faculty of Science, Beni-Suef University, Egypt.

\section{Discussion}

Egypt has a relatively long history of reptile nematology, mostly of the genera Agama and Scincus (Seurat, 1917; Baylis, 1923; Moravec et al, 1987). The morphological studies of the recorded species showed that it belonged to genus Thelandros (Wedl, 1861). Species of Thelandros are distinguished based on pattern of the caudal papillae, spicule length and morphology of the anterior cloacal lip in males, location of the vulva and morphology of the posterior end of the female and geographical distribution (Bursey and Goldberg, 2005). The recorded species can be differentiated from Parapharyngodon sp. based on the mouth bounded by three bilobed lips, the presence of three pairs of caudal papillae in male, the absence of gubernaculums and the tail of female is suddenly constricted behind anus to form a terminal spike.

Thelandros aegypti Amer (2004) is most morphologically and morphometricaly similar to the present nematode isolated. Both species resemble each other in; oral opening is surrounded by three bilobed lips; three pairs of male anal papillae, post-equatorial vulva in addition to the similar morphometric data. A comparison between the present species and some species of the same genus recorded was given (Tab.1).

Thelandros petterae Adamson and Nasher (1984a) differed from the present species in the flask shaped anal peduncles in males and the prevular swelling in females. T. agama Adamson and Nasher (1984a) differed from the species recorded in the present study in the absence of lips; caudal appendages and host locality. T. masaae Adamson and Nasher (1984a) differs from the present species in the presence of a long tubular extension supporting the vulva, the shape of female tail and the shape of the anterior anal lip in male.

The present species differed from T. popovi Adamson and Nasher (1984b) in the presence of lips, metric characters and host locality.

Thelandros sp. Rabie et al. (2012) differed from the present species in that; oral opening without lips, presence of two pit-like amphids at the lateral side of cephalic collarets, the number and position of caudal papillae and absence of male spicule. The recorded species should be classified as Thelandros aegypti with a new host records in Egypt.

\section{Conclusion}

Thelandros aegypti Amer (2004) was recorded from Uromastyx aegyptia (new host), North Sinai Governorate (new locality) during a general survey on parasites infecting lizards in Egypt.

The parasite was described morphologically and morphometrically by light microscopy. More phylogenetic studies are on-going to elucidate the taxonomy of such nematode.

\section{Acknowledgment}

This work was kindly supported by the Departments of Zoology, Faculties of Science, Cairo and Beni-Suef Universities.

\section{References}

Adamson, ML, 1981: Parapharyngodon osteopili n. sp. (Pharyngodonidae: Oxyuroidea) and 
a revision of Parapharyngodon and Thelandros. Syst. Parasitol. 3:105-17.

Adamson, ML, 1989: Evolutionary biology of the Oxyurida (Nematoda); Biofacies of a haplodiploid taxon. Adv. Parasit. 28:175-228.

Adamson, ML, 1990: Haplodiploidy in the Oxyurida: decoupling the evolutionary processes of adaptation and speciation. Ann. Parasitol. Hum. Comp. 65:31-5.

Adamson, ML, Nasher, A K, 1984a: Pharyngodonidae (Oxyuroidea: Nematoda) of Agama yemenensis in Saudi Arabia: hypothesis on the origin of pharyngodonids of herbivorous reptiles. Syst. Parasitol. 6, 4:299-318.

Adamson, ML, Nasher, AK, 1984b: Pharyngodonidae (Oxyuroidea: Nematoda) of Agama yemenensis in Saudi Arabia with notes on Parapharyngodon. Can. J. Zool. 62, 12:2600-9.

Baha El Din, Sherif, 2006: A Guide to Reptiles \& Amphibians of Egypt. Cairo: The American University in Cairo Press.

Baker, MR, 1987: Synopsis of the nematoda parasitic in amphibians and reptiles. Memorial University of Newfoundland, Occasional Papers in Biol.11:1-325.

Baylis, HA, 1923: Report on a collection of parasitic nematodes mainly from Egypt. Part I- Ascaridae and Heterakidae. Part II- Oxyuridae Part III- Camallanidae etc., with a note on prostmayria and an appendix on Acanthocephala. Parasitology 15, 1:1-3, 14-23, 24-38.

Baylis, HA, 1936: Nematoda. I. Ascaridoidea and Strongyloidea: The fauna of British India. Taylor and Francis, London, UK.

Bursey, CR, Goldberg, SR, 2005: Two new species of Pharyngodonidae (Nematoda: Oxyuroidea) and other nematodes in Agama caudospina (Squamata: Agamidae) from Kenya, Africa. J. Parasitol. 91:591-9.

Castazo-Fernandez, C, Zapatero-Ramos, L M, Solera-Puertas, MA, González-Santiago, P M, 1987: Descripción de Parapharyngodon lilfordi n. sp. (Oxyuroidea, Pharyngodonidae) en Podarcis-lilfordi (Reptilia, Lacertidae) de las Islas Baleares. Rev. Iber. Parasitol. 47:275-81.

Chatterji, RC, 1933: On a new nematode, Parapharyngodon maplestoni gen. nov., sp. nov., from a Burmese lizard. Ann. Trop. Med. Parasit. 27:131-4.

Cunningham, MW, 2000: Pathogenesis of group a streptococcal infections. Clin. Microbiol. Rev. 13:470-511.
Dung, BT, Bursey, CR, Goldberg, SR, 2009: A new species of Thalelandros (Nematoda, Oxyuroidea, Pharyngodonidae) in Leiolepis reevesi (Sauria, Agamidae) from Vietnam. Acta Parasitol. 54, 2:151-3.

Freitas, JFT, 1957: So^breosge^ neros Thelandros Wedl, 1862 e Parapharyngodon Chatterji, 1933, com descrica o de Parapharyngodon alvarengai sp. n. (Nematoda, Oxyuroidea). Mem. Inst. Oswaldo Cruz. 55:21-45.

García-Calvente, I, 1948: Revisión del género Pharyngodon y descripción de nueva species. Rev. Iber. Parasitol. 8: 367-410

Hering-Hagenbeck, SFBN, Petter, AJ, Boomker, J, 2002: Redescription of some Spauligodon spp., and Parapharyngodon spp., and of Skrjabinodon mabyae (Sandground, 1936) Inglis, 1968 (Pharyngodonidae: Oxyuroidea) from insectivorous South African lizards. Onderstepoort J. Vete. Res. 69:7-29.

Karve, JN, 1938: Some nematode parasites of lizards. Pages 251-258 in Livro jubilar do professor Lauro Travassos, editadopara commemorar o 25 aniversario de luas acatividades scientificas (1913-1938). Typographia do Instituto Oswaldo Cruz, Rio de Janerio, Brasil.

Moravec, F, Barus, V, Rysavy, B, 1987: Some parasitic nematodes, excluding Heterakidae and Pharyngodonidae, from amphibians and reptiles in Egypt. Fol. Parasitol. 34:255-67.

Nemtzov, SC, 2008: Uromastyx Lizards in Israel: NDF Workshop Case Studies. WG-7-Reptiles and Amphibians. Case Study 5. International Expert Workshop on CITES Non-Detriment Findings, Cancun, Mexico.

Rabie, SAH, Mohey El-din, Z, Abd El-Latif, Mohamed, NI, Abo Al-Hussin, OF, 2012: Redescription of Nematodes Pharyngodon mamillatus and Thelandros sp. from Some Reptiles of Qena, Egypt. Int. J. Sci. Res. 3, 11:1368-80.

Ramallo, G, Bursey, CR, Goldberg, SR, 2002: Parapharyngodon riojensis n. sp. (Nematoda: Pharyngodonidae) from the lizard Phymaturu spunae (Squamata: Iguania: Liolaemidae) from Northwestern Argentina. J. Parasitol. 88:979-82. Roca, V, 1999: Relación entre las faunas endoparásitas de reptiles y su tipo de alimentación. Rev. Esp. Herp. 13:101-21.

Seurat, LG, 1917: Sur les oxyures des sauriens du Nordafricain. Arch. Zool. Exp. Gen. 56:40144. 
Sharpilo, CP, 1976. Parasitic worms of the reptilian fauna of the USSR: Systematics, chorology, biology. Naukova Dumka, Moscow.

Skryabin, KI, Shikhobalova, NP, Mozgovoy, AA, 1951: Key to Parasitic Nematodes. Vol.2. Oxyurata and Ascaridata. Izdatel'-stvo Akademii Nauk S.S.S.R., Moscow (English translation by Amerind Publishing Co. Pvt. Ltd., New Delhi India, 1982).
Wedl, K, 1861: Zur Helminthenfauna Ägyptens. Akademie der Wissenschaften. Mathematisch Natur-wissenschaftliche. 44:463-82.

Wilms, T, Wanger, F, Shobrak, M, Böhme, W, 2010: Aspects of the ecology of the Arabian spiny-tailed lizard (Uromastyx aegyptia microlepis Blanford, 1875) at Mahazat asayd protected area, Saudi Arabia. Alamandra 46, 3:131-40

Table 1: Comparison between present Thelandros aegypti and some of same genus species previously recorded.

\begin{tabular}{|c|c|c|c|c|c|c|c|c|}
\hline Aspect & \multicolumn{4}{|c|}{ Male } & \multicolumn{4}{|c|}{ Female } \\
\hline & $\mathrm{BL}$ & BW & $\mathrm{OL}$ & TL & $\mathrm{BL}$ & BW & $\mathrm{OL}$ & $\mathrm{EL}(\mu \mathrm{m})$ \\
\hline $\begin{array}{l}\text { T. agama Adamson } \\
\text { and Nasher (1984) }\end{array}$ & $\begin{array}{c}2.29 \\
0.27-2.51 \\
\end{array}$ & 0.16 & 0.66 & 0.065 & $\begin{array}{c}5.64 \\
4.74-6.25 \\
\end{array}$ & $\begin{array}{c}0.5 \\
0.44-0.58 \\
\end{array}$ & 1.21 & $\begin{array}{r}95-120 \\
\times 62-68 \\
\end{array}$ \\
\hline $\begin{array}{l}\text { T masaae Adamson } \\
\& \text { Nasher (1984) }\end{array}$ & $\begin{array}{c}2.8 \\
2.2-3.56 \\
\end{array}$ & $\begin{array}{c}0.23 \\
0.18-0.25\end{array}$ & 0.92 & $\begin{array}{c}0.09 \\
0.07 \pm 0.09\end{array}$ & $\begin{array}{c}5.64 \\
4.74-6.25 \\
\end{array}$ & $\begin{array}{c}0.5 \\
0.44-0.58 \\
\end{array}$ & 1.21 & $\begin{array}{l}116-118 \\
\times 57-63 \\
\end{array}$ \\
\hline $\begin{array}{l}\text { T. petterae Adamson } \\
\text { \& Nasher (1984) }\end{array}$ & $\begin{array}{c}2.5 \\
2.31-2.54\end{array}$ & $\begin{array}{c}0.16 \\
0.15-0.18\end{array}$ & 0.87 & 0.077 & $\begin{array}{c}3.04 \\
2.95-3.3\end{array}$ & $\begin{array}{c}0.28 \\
0.31-0.32\end{array}$ & 1.18 & $\begin{array}{r}122-143 \\
\times 97-112\end{array}$ \\
\hline $\begin{array}{l}\text { Thelandros sp. } \\
\text { Rabie et al. (2012) }\end{array}$ & $1.85-3.02$ & $0.17-0.25$ & $0.48-0.65$ & $0.03-0.05$ & $2.65-3.85$ & $0.36-0.46$ & $0.66-0.76$ & $\begin{array}{r}78-84 \\
\times 51-68 \\
\end{array}$ \\
\hline $\begin{array}{l}\text { T. aegypti } \\
\text { Amer (2004) }\end{array}$ & $3.55-4.31$ & $0.28-0.32$ & $0.64-0.75$ & $0.06-0.07$ & $6.16-6.98$ & $0.45-0.59$ & $0.98-1.03$ & $\begin{array}{l}126-144 \\
\times 75-90 \\
\end{array}$ \\
\hline $\begin{array}{l}\text { T. aegypti } \\
\text { Rabie et al. (2012) }\end{array}$ & $2.85-3.6$ & $0.24-0.32$ & $0.48-0.65$ & $0.03-0.05$ & $3.65-4.8$ & $0.25-0.36$ & $0.76-0.98$ & $\begin{array}{r}78.7-84.3 \\
\times 51.34-68\end{array}$ \\
\hline $\begin{array}{l}\text { T. aegypti } \\
\text { (Present study) }\end{array}$ & $\begin{array}{c}3.0 \\
2.71-3.7\end{array}$ & $\begin{array}{c}0.24 \\
0.20-0.33\end{array}$ & $\begin{array}{c}0.58 \\
0.41-0.72\end{array}$ & $0.052-0.072$ & $\begin{array}{c}4.34 \\
3.32-4.73\end{array}$ & $\begin{array}{c}0.29 \\
0.24-0.39\end{array}$ & $\begin{array}{c}0.87 \\
0.76-0.98\end{array}$ & $\begin{array}{l}65.4-79.2 \\
\times 44.3-74\end{array}$ \\
\hline
\end{tabular}

BL: Body length, BW: Body width, OL: oesophagus length, TL: Tail length Measurements in mm, otherwise

\section{Explanation of figures}

Figs. 1-7: Light micrographs of Thelandros aegypti infecting Uromastyx aegyptia.

Fig. 1: Female, left lateral view terminated at a blind end, O oesophagus; VU vulva; BU bulb.

Fig. 2: Male, left lateral view terminated at a caudal spike and spicule (SP).

Fig. 3: Transverse cuticular annulations (TS).

Fig. 4: Anterior part of the worm body. (5) Posterior end of female.

Fig. 5: Female anal opening (A).

Fig. 6: Posterior end of male with a spicule (SP). Scale bars: $1=0.3 \mathrm{~mm} ; 2=0.2 \mathrm{~mm} ; 3-7=0.06 \mathrm{~mm}$ 


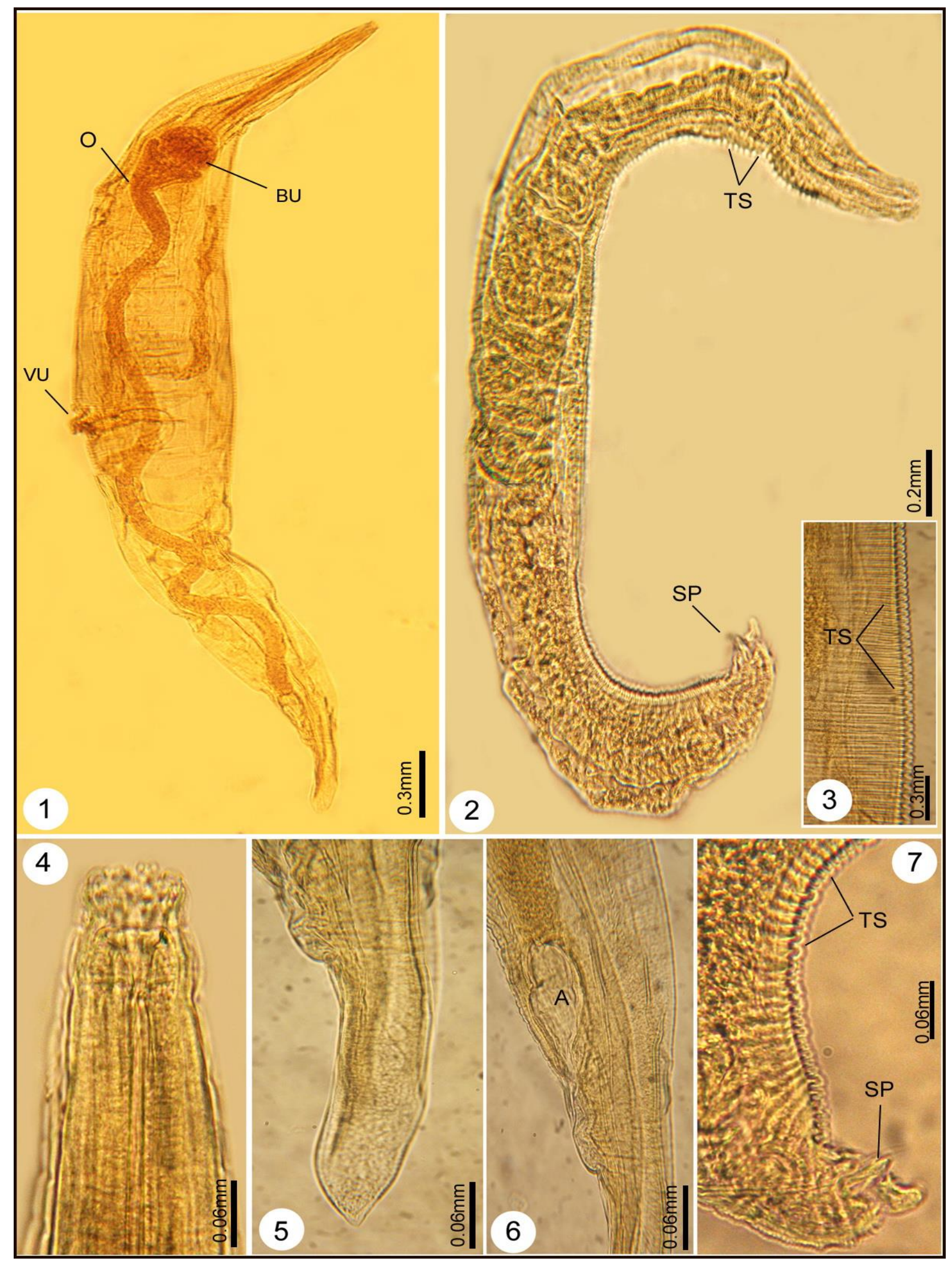

